\title{
Disturbance and subsequent recovery of mid-shore assemblages on seasonal, tropical, rocky shores
}

\author{
Neil Hutchinson ${ }^{1,2}$, Gray A. Williams ${ }^{1, *}$ \\ ${ }^{1}$ The Department of Ecology \& Biodiversity and The Swire Institute of Marine Science, University of Hong Kong, \\ Pokfulam Road, Hong Kong \\ ${ }^{2}$ Present address: Marine Biological Association, The Laboratory, Citadel Hill, Plymouth PL1 2PB, United Kingdom
}

\begin{abstract}
Hong Kong experiences a strongly seasonal climate, with distinct hot, wet summers and cool, dry winters, which has a great influence on intertidal assemblages. The impacts and relative importance of disturbance events on assemblage structure and subsequent recovery in this environment were examined on semi-exposed rocky shores. In August 1997, Typhoon Victor affected Hong Kong coastal waters bringing high seas and strong winds. Effects on mid-shore assemblage structure were patchy, with an increase in free space and a decrease in the abundance of the dominant molluscan grazer Monodonta labio occurring on one $10 \mathrm{~m}$ site on a shore, but not at other areas $10 \mathrm{~s}$ of $\mathrm{m}$ away. The long-term impacts of this pulse disturbance were, however, negligible, as at this time of year there is little algal cover and grazer abundances are low, due to predictable annual disturbance caused by an increase in temperature with the onset of summer. Monitoring of plots artificially disturbed at different times of the year showed that recovery to undisturbed conditions was rapid following pulse disturbance events such as typhoons. Such disturbances had no lasting (>6 mo) effect, as the die-off of species in the summer caused assemblages on shores to dissipate, and any long-term impacts of these disturbances were not obvious after one summer. It appears that the short-term effects of pulse disturbances on Hong Kong shores are rapidly eclipsed by annual, summer die-off events.
\end{abstract}

KEY WORDS: Hong Kong · Tropical rocky shores · Succession · Disturbance · Typhoon · Summer die-off $\cdot$ Seasonal variation

\section{INTRODUCTION}

Disturbance is a primary cause of the creation of free space on rocky shores, resulting in assemblage heterogeneity in many habitats (Dayton 1971, Sousa 1984, Aronson \& Precht 1997). It allows the colonisation and growth of competitively inferior species to occur (see review by Pickett \& White 1985), utilising areas previously unavailable (Moore 1939, Townsley et al. 1962) and thus increasing patchiness at a variety of spatial scales (Pye Finch 1943, Paine \& Levin 1981, Menge et al. 1993). The magnitude of disturbance events and the exact timing of free-space creation have been shown to be important in shaping the structure of intertidal assemblages (Sousa 1979a, Lively et al. 1993), and may have a direct effect on subsequent patterns of re-

*Corresponding author. Email: hrsbwga@hkucc.hku.hk colonisation (Underwood et al. 1983, Blanchette 1996), as temporal variation in propagule availability (Sousa 1984, Hoffmann \& Ugarte 1985), increased levels of physical stress (Moore 1972, Bell 1993), and predation (Garrity \& Levings 1981, Underwood \& Jernakoff 1984) can lead to different species utilising the free space made available at different times of the year.

Several studies of colonisation and subsequent recovery, the stage at which assemblage structure in disturbed areas reaches the same state as adjacent undisturbed areas, of newly created free space have focused on the events that result in space being made available, including scouring of the substrate (Shanks \& Wright 1986, McQuaid \& Dower 1990, McCook \& Chapman 1993, van Tamelen 1996), periods of high heat stress (Isaac 1933, Menge \& Sutherland 1987), 
storm damage (Dayton 1971, Alvarado et al. 2001) and oil spills (Stirling 1977, Southward \& Southward 1978, van Tamelen et al. 1997). The unpredictable nature of disturbance events, however, often makes it difficult to follow an assemblage from its pre-disturbance phase to its re-colonisation and subsequent recovery.

Spatial and temporal variation in the composition of Hong Kong's intertidal assemblages, species recruitment and survival have previously been described by Hodgkiss (1984), Williams (1993) and Kaehler \& Williams (1997). Assemblage variability is, to a great extent, linked to the seasonal nature of the Hong Kong climate (Kaehler \& Williams 1996), with the hot, wet summer season imposing high levels of physical stress on intertidal assemblages. In particular, disturbance events such as increased temperatures, coupled with low daytime tides, lead to high thermal stress (Hodgkiss 1984, Williams \& Morritt 1995, Williams \& McMahon 1998), and severe storm damage can occur due to typhoons (Williams 1994, Nagarkar 1996, Nagarkar \& Williams 1999). Although some of the changes following these events are known, most information is anecdotal (Morton \& Morton 1983) and very little has been documented of the time-scale of freespace creation, species affected by disturbance events or spatial variation in assemblage structure. The fact that free-space creation occurs following increased levels of physical stress and typhoon damage in summer, however, makes it possible to track these events through from the creation of free space onwards, as they are somewhat predictable.

Work presented here investigates temporal patterns of change in assemblage structure related to disturbance events on semi-exposed rocky shores in Hong Kong. Patterns of recovery are examined following natural typhoon damage and after simulated disturbances in summer and winter periods. The relative long-term impacts of these pulse disturbance events are investigated in conjunction with an examination of the rate of die-off during predictable periods of elevated physical stress in summer.

\section{MATERIALS AND METHODS}

Study sites. Experiments and observations were conducted on unbroken stretches of semi-exposed rocky shore (as defined by Kaehler \& Williams 1996), at $1.5 \mathrm{~m}$ above Chart Datum (CD, see Hong Kong Observatory 1997), in a zone of high algal and grazer diversity. This height falls between the 'bare-zone' and 'mixed-zone' of Kaehler \& Williams $(1996,1997)$ and is referred to as the mid-shore (Kaehler \& Williams 1996, 1997). The exposure and shore aspect at sites in this study were such that assemblage structure at $1.5 \mathrm{~m}$ CD was more similar to the 'mixed-zone' than the area of reduced cover (the 'bare-zone') recorded by Kaehler \& Williams $(1996,1997)$.

Wave action in Hong Kong is highest during winters and at times when typhoons affect the region (Morton \& Morton 1983), and can lead to physical disturbance in the form of scouring (Nagarkar \& Williams 1999).

Natural disturbance-typhoon damage. During July 31 to August 2, 1997, Typhoon Victor affected Hong Kong coastal waters with gusts of winds up to $135 \mathrm{~km} \mathrm{~h}^{-1}$ (Hong Kong Observatory 1997). Typhoon Victor was the strongest tropical cyclone to hit Hong Kong since 1983 and, while it was the first to affect Hong Kong during 1997, it occurred later in the year than any other recorded since 1946 (Hong Kong Observatory 1997). Routine sampling of sites for a separate study (Hutchinson 1999) was fortuitously conducted $2 \mathrm{~d}$ before the typhoon hit Hong Kong, and when the site at Wah Fu $\left(22^{\circ} 15^{\prime} \mathrm{N}, 114^{\circ} 08^{\prime} \mathrm{E}\right)$ was revisited on August $4,3 \mathrm{~d}$ after the typhoon, it was apparent that the typhoon had denuded certain areas of the shore at the site. Surveys were therefore conducted on transects at Wah Fu following this disturbance event.

Three $10 \mathrm{~m}$ long transects (WF1 to WF3), 10 to $50 \mathrm{~m}$ apart, parallel to the waterline in the mid-shore, were surveyed prior to and following the typhoon to determine sessile and mobile species abundance. Ten randomly placed, 100 point, double-strung $50 \times 50 \mathrm{~cm}$ quadrats were placed centrally on each transect. Percentage cover was determined by scoring and identifying algae and sessile species that occurred beneath string intersections. Mobile species were scored when $>50 \%$ of the animals' body area fell within the quadrat, and when these species were directly beneath string intersections, the percentage cover of sessile organisms was adjusted accordingly. To quantify epilithic chlorophyll a (chl a) concentration, as an estimate of standing crop, 10 rock chips $\left(\sim 3 \mathrm{~cm}^{2}\right)$ were randomly removed from each transect by hammer and chisel. Once collected, samples were stored in dark, damp conditions until transferred to the laboratory, where chl a was extracted using the cold methanol method within 4 h of collection (see Nagarkar \& Williams 1997). Following the typhoon, both chl a and species abundance data were initially collected on a weekly basis for $4 \mathrm{wk}$, and then on a monthly basis, to examine initial recruitment and subsequent recovery of the disturbed sites.

A comparison of percentage free space was made between all transects, before (within $7 \mathrm{~d}$ ) and after (within 7 d) Typhoon Victor, using a 2-factor ANOVA to test the null hypotheses that there were no differences between transects (3 levels = transects; orthogonal and random), times (2 levels = before, after; orthogonal and fixed), or an interaction between these factors 
that would indicate spatial variation in typhoon damage. The same model was used to determine how the abundance of the dominant grazer Monodonta labio varied prior to and following the typhoon. Change in chl a concentration was not analysed, however, as this variable was not recorded prior to the typhoon. Data for all analyses were checked for homogeneity of variances (Cochran's $C$-test) and transformations were performed where necessary to satisfy assumptions of homogeneity of variances. Significant differences for fixed factors were further examined, where appropriate, using SNK multiple comparison tests (Zar 1996, Underwood 1997).

Simulation of disturbance - experimental plots. To investigate whether patterns of succession and recovery were governed by the timing of disturbance, disturbance events were simulated at different times of the year in a $\sim 20 \mathrm{~m}^{2}$ area that was selected adjacent to the transects at Wah Fu. Experimental plots $(25 \times$ $25 \mathrm{~cm}$ ) were marked on the shore between 1.25 and $1.75 \mathrm{~m} \mathrm{CD}$ with short brass screws at opposite corners to allow repeated sampling. Plots were situated on rock surfaces with a slope of $<45^{\circ}$ in a relatively homogenous area with few cracks, no rock pools and similar rock roughness (roughness coefficient $=1.07 \pm$ 0.4 SD, Hobson 1972, Kostylev 1996) to minimise variation between plots. Plots were created $4 \times 4 \mathrm{~cm}$ larger than the area being studied to give a $2 \mathrm{~cm}$ margin to allow for possible edge effects (Foster 1975, Hawkins \& Hartnoll 1983). Plots were 'disturbed' by abrading the rock surface for 4 min with a wire brush, which scoured and damaged algae and any sessile invertebrates present. The plot was then rinsed with seawater and rubbed by hand to remove any debris. This method of disturbance was used to simulate scouring that occurs on rocky shores during periods of high wave action such as storms and typhoons (Kohn \& Leviten 1976, Daly \& Mathieson 1977, Dye 1993). An 'undisturbed' plot was lightly rubbed for the same period of time by hand and then also rinsed.

During the study, which ran from January 1997 to December 1998, algal and faunal abundance in plots was scored immediately before and after plot creation and disturbance, weekly for $4 \mathrm{wk}$ and then on a monthly basis, which allowed the more immediate changes over the first month to be monitored before establishing a sampling regime of longer duration. Five disturbed and 5 undisturbed randomly determined plots were created twice a year at spring low tides in the period before the mean coolest and hottest months of the year, January and July respectively (Kaehler \& Williams 1996, Kennish et al. 1996). This time-scale was followed so that space in the experimental areas would be available for potential settling species immediately before winter and summer, the
2 annual extremes of climate. In total, 40 plots were created over the $2 \mathrm{yr}$ of the study $\left(\sum \mathrm{n}=[5\right.$ disturbed +5 undisturbed] $\times 2$ seasons $\times 2 \mathrm{yr}=40$ ).

Changes in percentage cover of algae and sessile organisms and mobile species abundance were recorded using a $25 \times 25 \mathrm{~cm}, 100$ point, double-strung quadrat. The duration of observations ran for 6 to 25 mo, depending on when plots were created. Percentage cover of algae and free space were compared after 6 mo of plot creation to allow comparisons among the 4 temporal sets of experiments. Rock chips $\left(\sim 3 \mathrm{~cm}^{2}\right)$, were randomly collected from each plot for chl $a$ analysis prior to and after disturbance, 1 wk later, 1 mo later, and then every 3 mo from January 1997 to February 1999. This removed an area of $<15 \%$ of the plots that was not included in subsequent surveys. A 3 -factor ANOVA was performed to test the null hypotheses that there were no differences in percentage cover in plots created in different years (2 levels; orthogonal and random), seasons (2 levels, winter and summer; orthogonal and fixed) and between disturbance treatments (2 levels; orthogonal and fixed) or possible interactions between these factors.

Natural disturbance-summer die-off of algae. Surveys were conducted to examine the rate at which space-occupying species, principally algae, disappeared from the shore with the onset of summer, when physical conditions became more harsh as temperatures increased. To determine the amount of freespace created by algal die-off, at intermediate spatial scales $(<200 \mathrm{~m}$ within a shore), 3 sites (A to C) were randomly selected at Cape d'Aguilar $\left(22^{\circ} 13^{\prime} \mathrm{N}\right.$, $\left.114^{\circ} 12^{\prime} \mathrm{E}\right)$. Using the methods described for typhoon damage, surveys of algal cover were conducted on a weekly basis and grazer abundance on specific dates at the beginning (March 30), middle (April 30) and end (May 17) of the study. As mean air temperatures started to rise from $\sim 22$ to $26^{\circ} \mathrm{C}$ in mid-April (Hong Kong Observatory 1997), surveys were intensified and conducted every $3 \mathrm{~d}$ to examine small-scale temporal changes, as it was postulated that die-off would occur over a shorter time period at this time. More intense sampling was conducted at 3 times during the study, on April 20, May 3 and May 15, when surveys were conducted at daily intervals for $3 \mathrm{~d}$ to determine smaller-scale temporal changes. Chl a concentration was examined by taking 10 random rock chips from each transect on each sampling date.

Variation in percentage cover of algae, variation in chl $a$ and grazer abundance on transects were examined using a 2-factor ANOVA to examine the null hypotheses that there were no differences between sites ( 3 levels; orthogonal and random) with dates (3 levels, i.e. March 30, April 30 and May 17; orthogonal and fixed) and no interaction between location and 


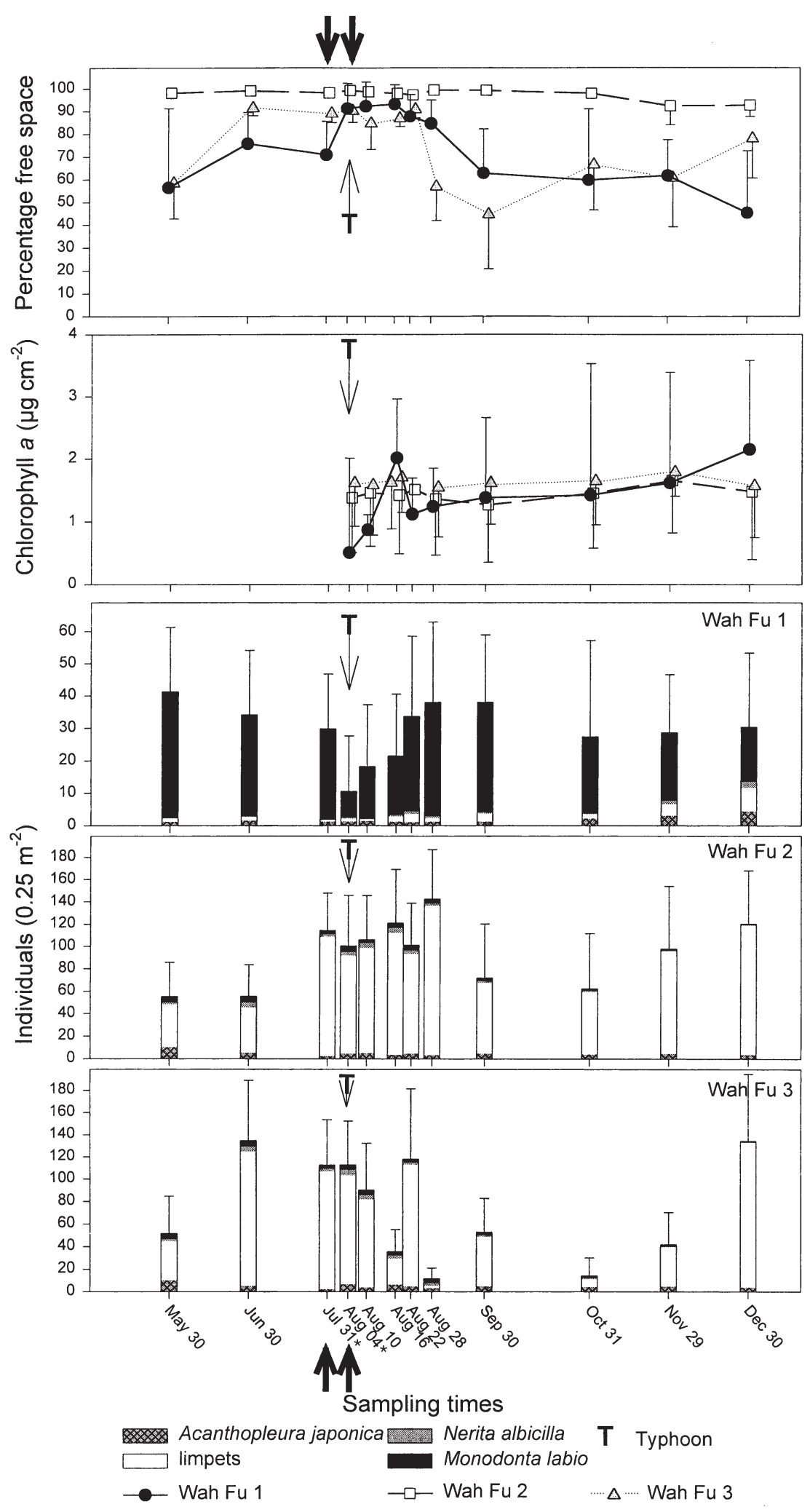

Fig. 1. Variation in percentage free space $( \pm \mathrm{SD}, \mathrm{n}=10), \mathrm{chl} a( \pm \mathrm{SD}, \mathrm{n}=10)$ and grazer abundance (+SD for total grazers, $n=10$ ) at Wah Fu Sites 1 to 3, before and after Typhoon Victor in early August 1997. Bold arrows and asterisks indicate dates used in statistical analysis time. Although on each sampling date a different set of random quadrats were surveyed, all dates were not compared due to possible problems with temporal non-independence of data.

\section{RESULTS}

\section{Natural disturbance - typhoon damage}

The effects of Typhoon Victor were relatively minor and were only apparent on one of the transects, WF1, at Wah Fu. Percentage free space increased from $\sim 70$ to $90 \%$ on this transect (Fig. 1) following the typhoon, as indicated by a significant interaction between date and transect (Table 1). Areas of newly created free space were usually small patches $\left(<10 \mathrm{~cm}^{2}\right)$, scoured by cobbles washed up onto the shore, although a $1 \mathrm{~m}$ section of the transect was completely covered by cobbles from the period following the typhoon until observations ended in July 1999.

Re-colonisation of free space on the transect at WF1 was initiated with growth of a thin film of Hildenbrandia rubra at the end of August, followed by slower increases in Hapalospongidion gelatinosum and Ralfsia expansa (authors' pers. obs.). While the area below the transect did not recover, as it was buried under cobbles, there was no apparent long-lasting effect on the transect itself (Hutchinson 1999).

In the month following the typhoon, there was a gradual increase in the mean concentration of chl $a$, with levels peaking at $\sim 2 \mu \mathrm{gm}^{-2}$ on August 16 (Fig. 1). Grazer abundance also decreased on this transect during this period following the typhoon (Fig. 1), with a significant change in the abundance of Monodonta labio after the typhoon on WF1 (Table 1). The initial decrease in this species was, however, followed by a steady increase in numbers of adults over the next 3 wk, with levels reaching those found before the disturbance event (Fig. 1). No such changes were observed on either of the other 2 transects. 
Table 1. Comparison using a 2-factor ANOVA of percentage free space and abundance of the dominant grazer, Monodonta labio, at Wah Fu before and after Typhoon Victor, by date and transect. Free space data were arc-sine-transformed to homogenise variances. Significant differences are shown in bold and fixed factors are further analysed using SNK tests ${ }^{\text {snk }}$ ). WF1 to WF3 are Wah Fu Sites 1 to 3 respectively

\begin{tabular}{|c|c|c|c|c|c|c|c|}
\hline \multirow[t]{2}{*}{ Source } & \multirow[t]{2}{*}{ df } & \multicolumn{3}{|c|}{ Free space } & \multicolumn{3}{|c|}{ Monodonta labio } \\
\hline & & MS & $F$ & $\mathrm{p}$ & MS & $F$ & $\mathrm{p}$ \\
\hline Date & 1 & 464.61 & 6.44 & 0.014 & 12.23 & 22.97 & $<0.001$ \\
\hline Transect & 2 & 1285.1 & 17.82 & $<0.001$ & 49.20 & 92.39 & $<0.001$ \\
\hline Date $\times$ Transect & 2 & 464.61 & 6.44 & $0.003^{\text {snk }}$ & 12.23 & 22.97 & $<0.001^{\text {snk }}$ \\
\hline Residual & 54 & 72.12 & & & 0.53 & & \\
\hline SNK tests & & $\begin{array}{l}\text { WF1 Be } \\
\text { WF2 Be } \\
\text { WF3 Be }\end{array}$ & $\begin{array}{l}\text { After } \\
\text { After } \\
\text { After }\end{array}$ & & $\begin{array}{l}\text { WF1 } \\
\text { WF2 } \\
\text { WF3 }\end{array}$ & $\begin{array}{l}>\text { After } \\
=\text { After } \\
=\text { After }\end{array}$ & \\
\hline
\end{tabular}

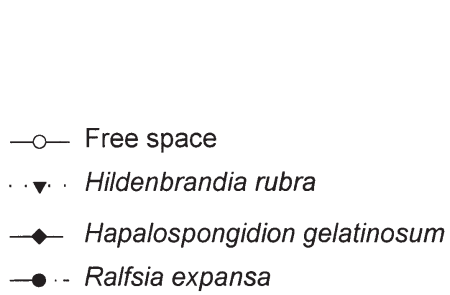

Fig. 2. Free space and algal cover in disturbed and undisturbed plots created in $1997(+\mathrm{SD}, \mathrm{n}=5)$. The initial point is for plots prior to scrubbing. Bold arrows and asterisks indicate dates used in statistical analysis

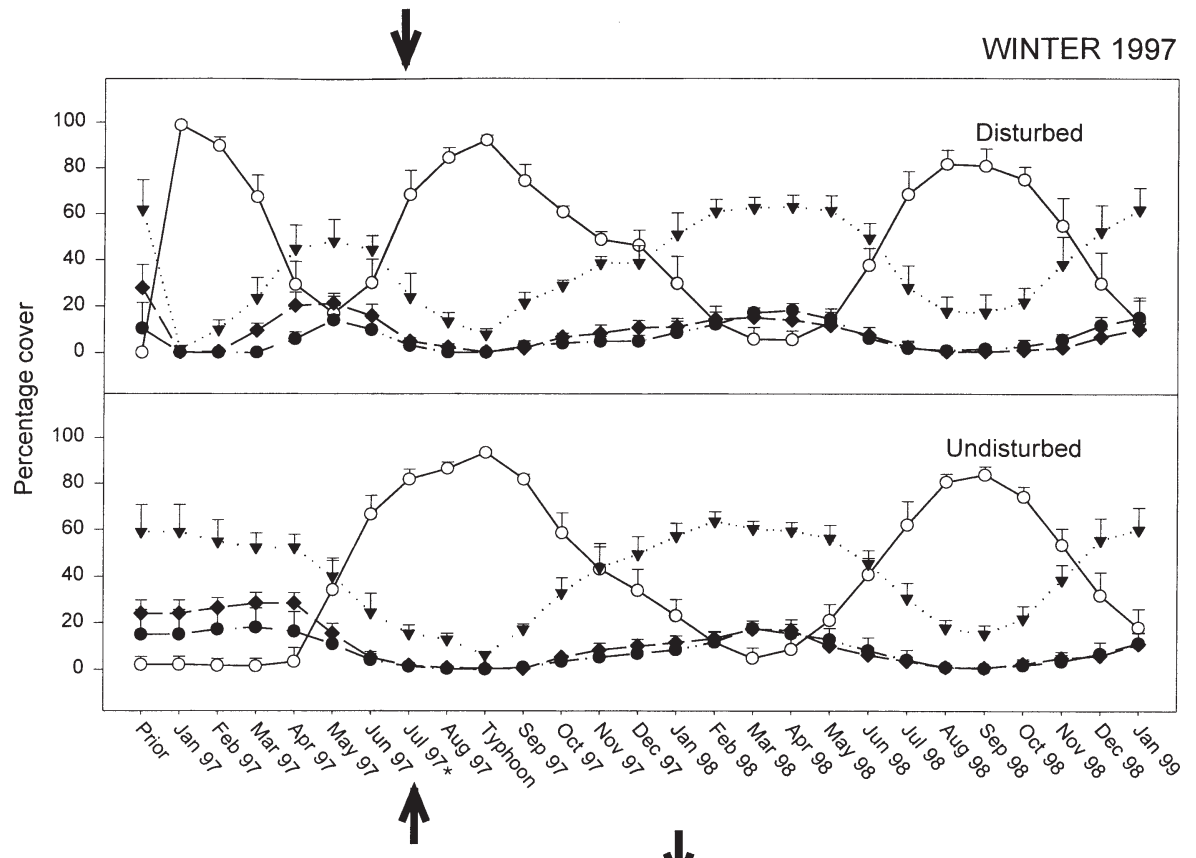

\section{Simulation of disturbance - experimental plots}

Experimental disturbance of plots initially caused a large increase in percentage free space in disturbed as compared to undisturbed plots, particularly during the winter. These changes, however, disappeared after several months, regardless of season or year of plot creation (Figs. 2 \& 3).

All plots created in summer and winter in 1997 and 1998 contained a similar complement of encrusting algae at the end of the study (Figs. 2 \& $3)$. Broad patterns were the same as seen on the adjacent, typhoon-disturbed, transect with initial colonisation in all plots by the red encrusting alga Hildenbrandia rubra, which was the primary space occupier, followed by the brown encrusting algae Ralfsia expansa and Hapalospongidion gelatinosum (Figs. $2 \& 3$ ). Some of the

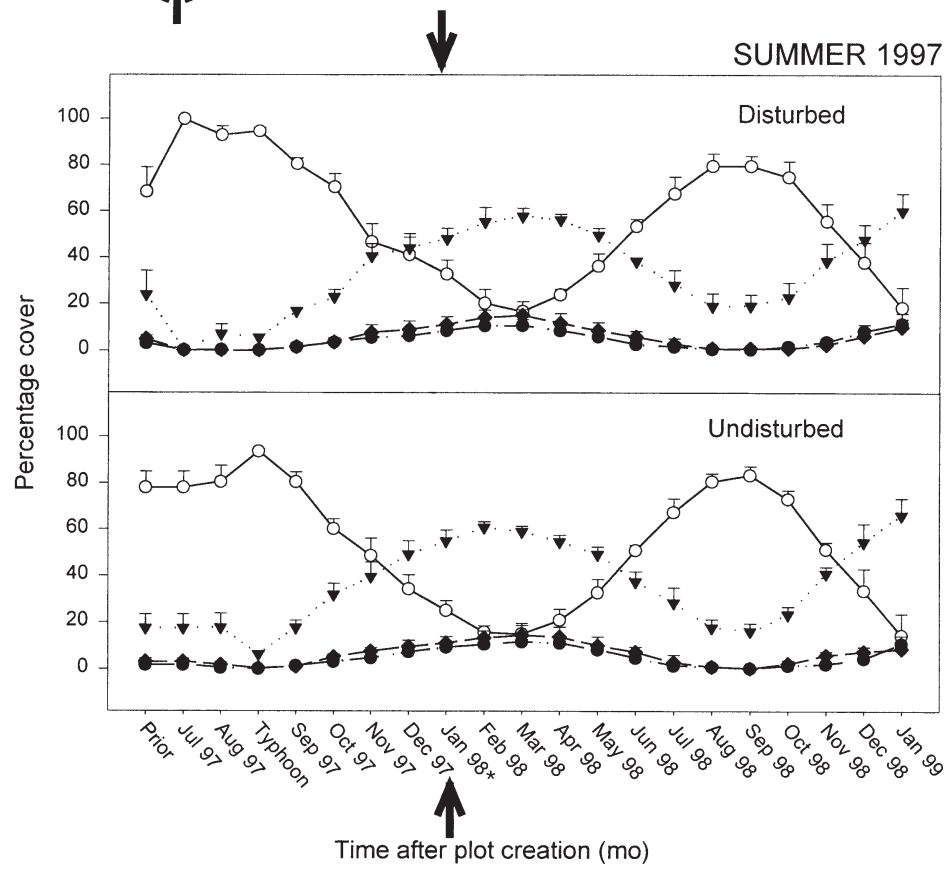




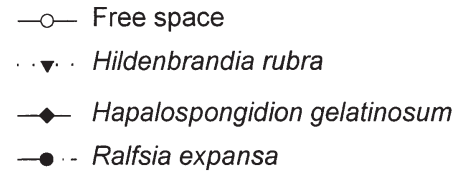

Fig. 3. Free space and algal cover in disturbed and undisturbed plots created in $1998(+\mathrm{SD}, \mathrm{n}=5)$. The initial point is for plots prior to isks indicate dates used in statistical analysis scrubbing. Bold arrows and aster-

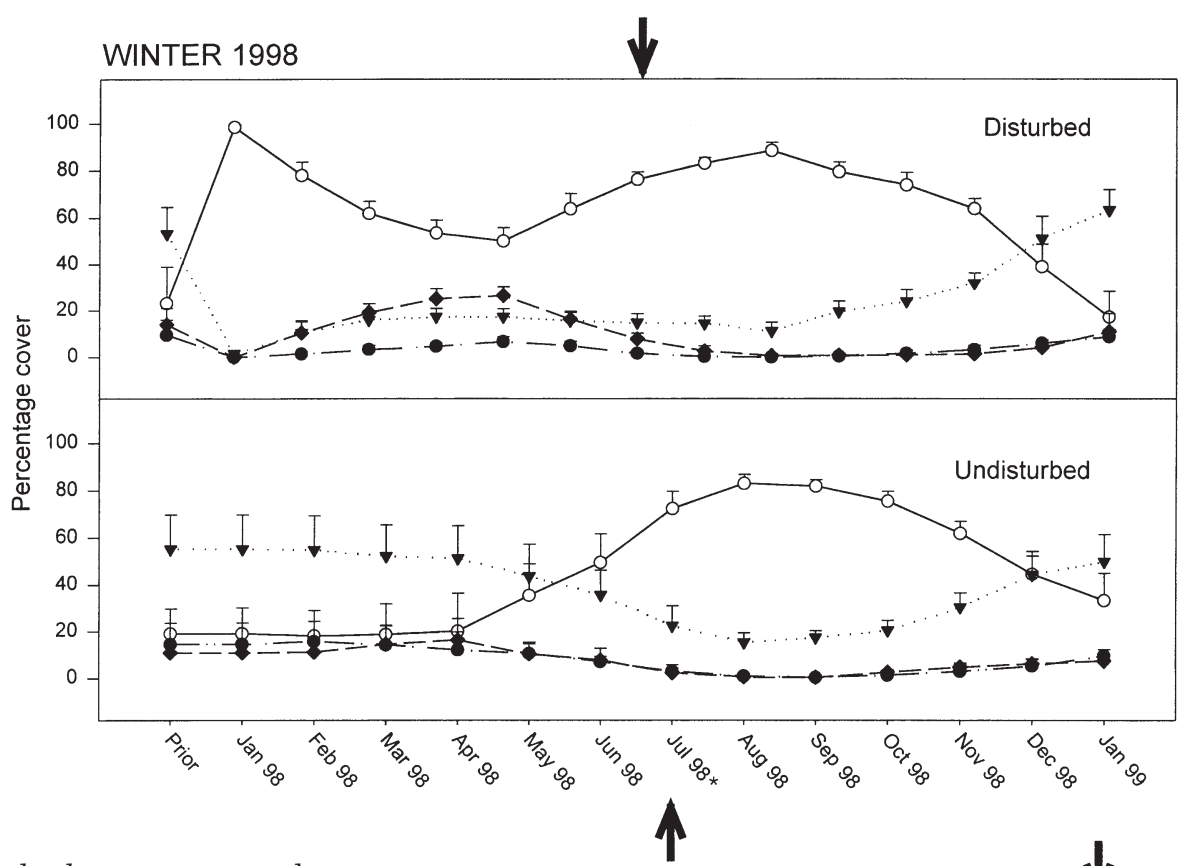

plots contained individuals of Endopleura aurea and Ralfsia endopluroides, but as these accounted for $<0.1 \%$ of overall cover, they were not examined further. At no time were erect algal species found in any plots, and grazers were rarely found. During the summer of 1997, both disturbed and undisturbed plots were affected by Typhoon Victor, which caused a sudden decrease in percentage cover in all plots created in winter and summer 1997 (Fig. 2).

Analyses showed significant interactions between experimental treatment, year and season (Table 2) for percentage of free space and cover of the algae Hildenbrandia rubra, Hapalospongidion gelatinosum and Ralfsia expansa, suggesting that variation between different treatments, 6 mo after their creation, were not consistent between seasons in each year (Figs. 2 \& 3). A seasonal change in percentage cover was apparent in all plots regardless of treatment, season or year of plot creation, with increases in free space during summer, and cover of algae in winter (Figs. 2 \& 3). A similar trend was also apparent for chl a levels, which also peaked in winter and dropped in summer (Fig. 4). Higher chl a concentrations were recorded in winter than in summer, but there were no differences between the year of plot creation or treatment 6 mo after disturbance (Table 2).

The newly created free space in plots disturbed during winter was immediately colonised by the 3 most abundant encrusting algae that were already present in the undisturbed plots; in summer, colonisation did not occur until 2 mo after plot creation (Figs. 2 \& 3). An increase in free space, associated with this die-off, occurred in all treatments with the onset of summer in both years, and subsequent re-colonisation in winter was also consistent across treatments (Figs. $2 \& 3$ ).

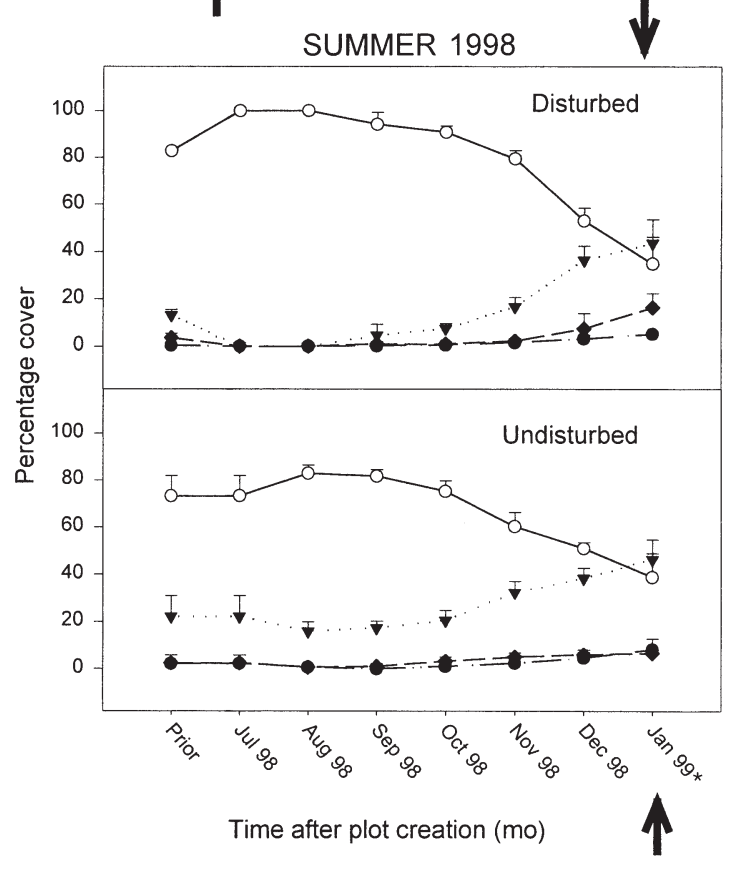

The major differences in free-space availability and algal cover between treatments were seen in the early period of winter, 1 to 2 mo following simulated disturbance. There was an obvious pattern in both years where cover of algae and chl a levels increased in winter and decreased in summer (Figs. 2 to 4 ). While disturbance led to an initial drop in cover of all algae and chl a levels in summer and winter during both years, recovery was swift. In the 2 to 3 mo period following disturbance in winter 1997 and 1998, percentage cover of Hapalospongidion gelatinosum, Ralfsia expansa and Hildenbrandia rubra recovered to a level close to that found in undisturbed plots (Figs. 2 \& 3). 


\section{Natural disturbance - summer die-off of algae}

With the onset of increased levels of physical stress during the summer, free space on sites at Cape d'Aguilar increased considerably at Sites A to C, eventually reaching levels of $90 \%$ at all sites on May 17 (Fig. 5). A significant interaction was found for all species and chl a levels between date and transect, suggesting variation in the timing of the die-off on the different transects (Table 3). The first species to disappear from the shore was the patchily distributed, erect alga Endarachne binghamiae, which disappeared from all sites by April 22 (Fig. 5; no analysis was conducted on this species as it was not present on either April 30 or May 17). For the fleshy encrusting algae, Ralfsia expansa, Hildenbrandia rubra and Hapalospongidion gelatinosum, the greatest algal dieoff occurred from the middle of April to the beginning of May. Rates of decrease in percentage cover of the different species varied between sites, for example, while cover of Hapalospongidion gelatinosum at Site B dropped from $\sim 10$ to $<2 \%$ during a $72 \mathrm{~h}$ period up to April 22, a similar decrease was not recorded at Site A until May 4, when cover dropped from $\sim 8$ to $<2 \%$ in
24 h (Fig. 5). By May 17, however, cover of each species was negligible $(<5 \%)$ at all sites.

The main space occupier on transects at Sites A to C at the end of the study was coralline algae, with cover of $\sim 5 \%$ at all sites of bleached tissue and $\sim 2 \%$ unbleached tissue, as compared to $\sim 1$ to $6 \%$ of unbleached tissue at the beginning of the study (Fig. 5). As not all bleached tissue was necessarily dead, analysis was conducted using pooled data for both unbleached and bleached tissue, and no significant differences were found between dates or transects (Table 3).

Chl a levels decreased with time at all sites by approximately $30 \%$ ( 0.8 to $\left.0.9 \mu \mathrm{g} \mathrm{cm}^{-2}\right)$, with consistently higher concentrations at Site $\mathrm{C}$ than Sites A and B (Fig. 6). Analysis showed a significant interaction between date and transect (Table 3), suggesting that the rate of die-off of epilithic algae and biofilm species differed between sites (Fig. 6). Total grazer abundance varied between the transects at Sites A to C (Table 3), with greater density at Site C than A and B (Fig. 7). Abundance decreased at all sites from March 30 to April 30 (Table 3), especially for the limpet Patelloida saccharina (Fig. 7).

Table 2. Comparison using a 3-factor ANOVA of percentage cover of encrusting algae and chl a concentration 6 mo after plot creation by year of plot creation (Y), season of creation (S) and disturbed (D)/undisturbed (U) treatments (Tr). Free space, Hildenbrandia rubra and Ralfsia expansa data were arc-sine-transformed where necessary to homogenise variances. Significant differences are shown in bold and fixed factors are further analysed using SNK tests ${ }^{(\mathrm{snk})}$

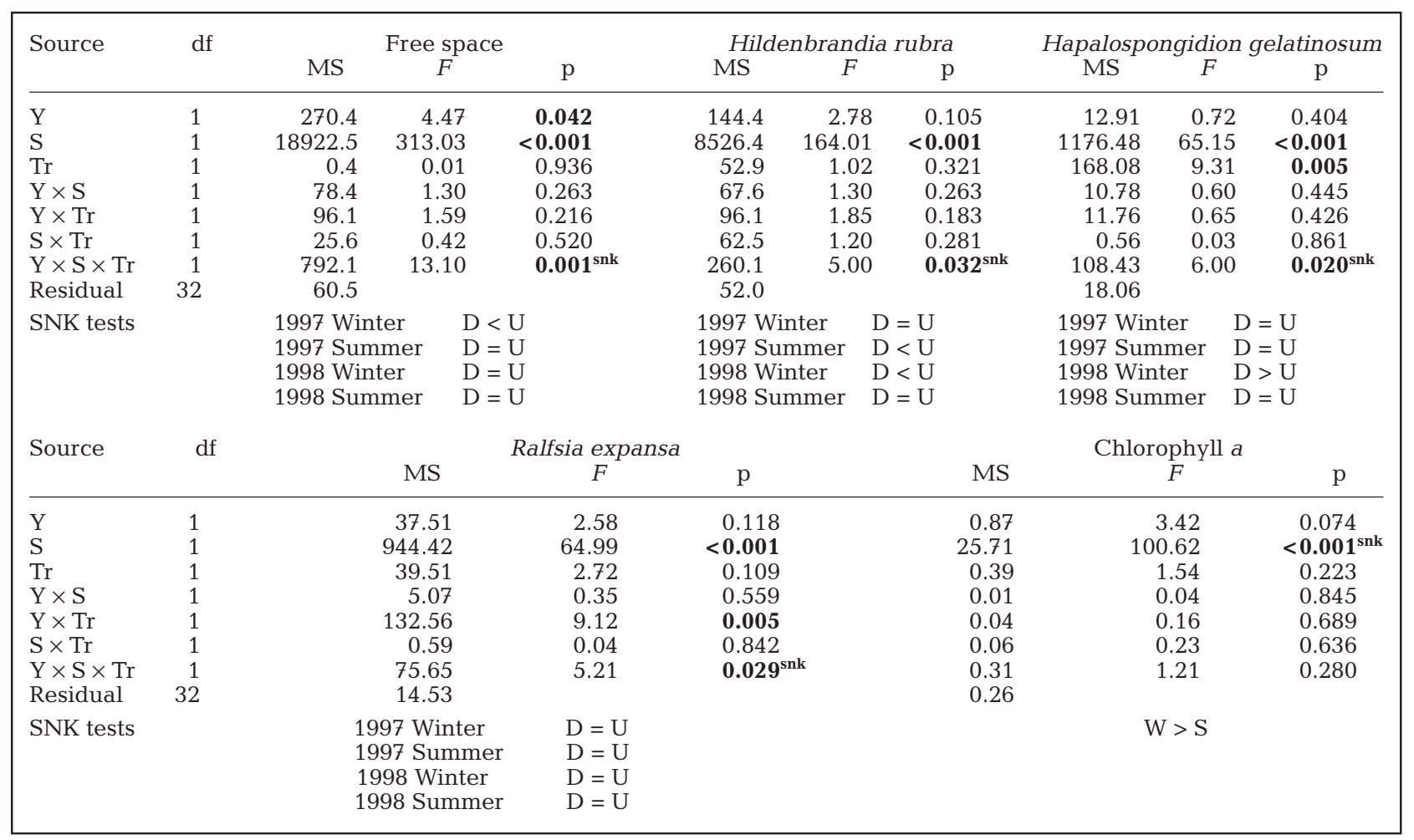



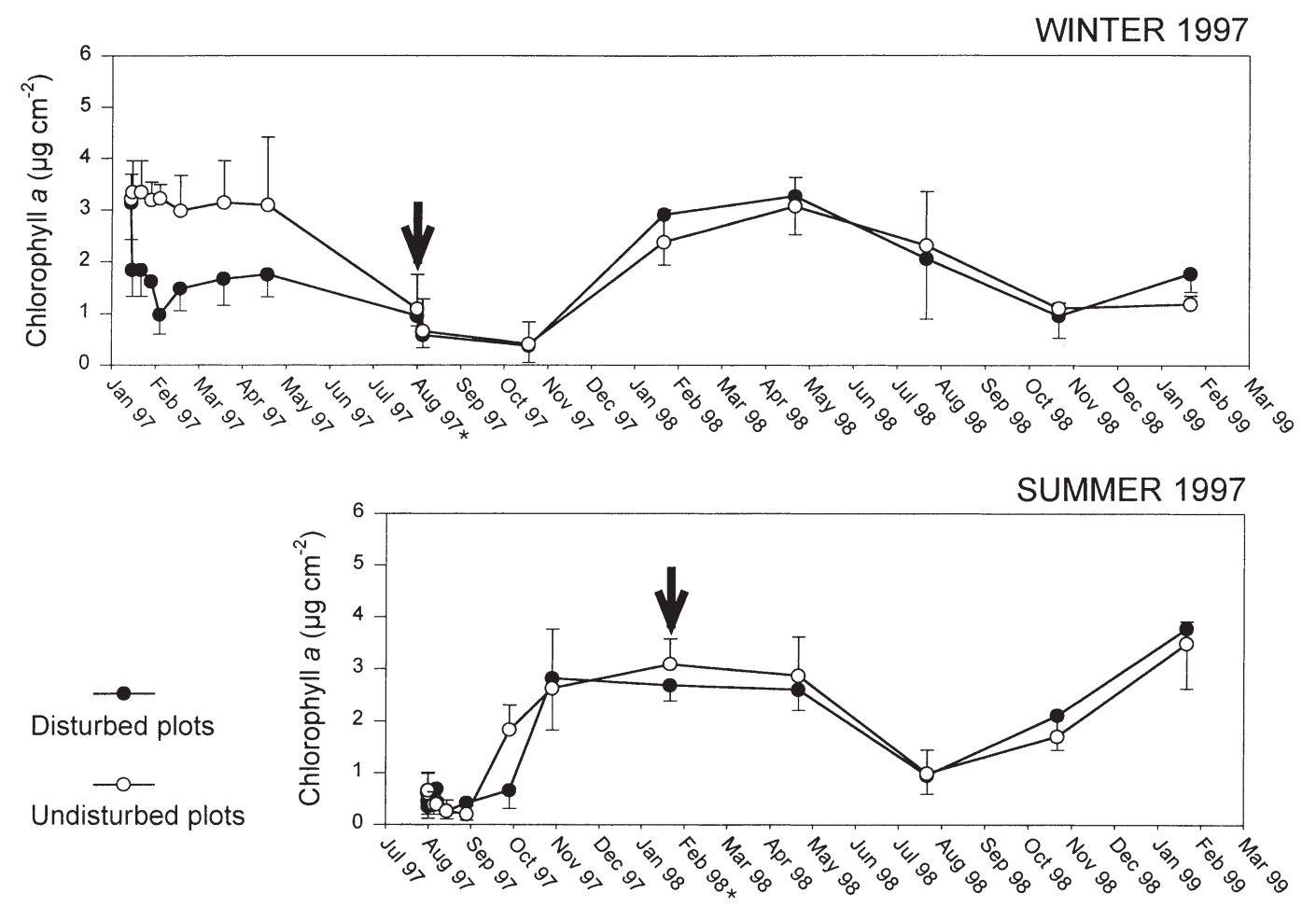

Fig. 4. Variation in chl a levels following plot creation in 1997-1998 (+SD for disturbed plots, $-\mathrm{SD}$ for undisturbed plots, $\mathrm{n}=10$ ). Note scale change for winter 1998. The initial point is for plots prior to scrubbing. Bold arrows and asterisks indicate dates used in statistical analysis

\section{DISCUSSION}

The Hong Kong intertidal is characterised by a strong seasonal component. Natural or simulated disturbances at different times of the year did not lead to long-term (>6 mo) changes in mid-shore assemblage structure on semi-exposed Hong Kong rocky shores. Rather, while the disturbance events initially resulted in the creation of patches of free space, patterns of recruitment were such that recovery was swift. This is in direct contrast to studies elsewhere in the world (Sousa 1979a, Hartnoll \& Hawkins 1985, Davis \& Wilce 1987, Benedetti-Cecchi \& Cinelli 1993, Dye 1993), which have shown that the creation of such space at different times of the year can lead to the formation of a mosaic of patches at different successional stages that, if not further disturbed, may take several years to recover (e.g. 2 to 3 yr; Sousa 1979b).

The increased levels of physical stress and high temperatures that occur during the summer each year can essentially be viewed as an annual disturbance event that effectively 'over-rides' pulse disturbances that may
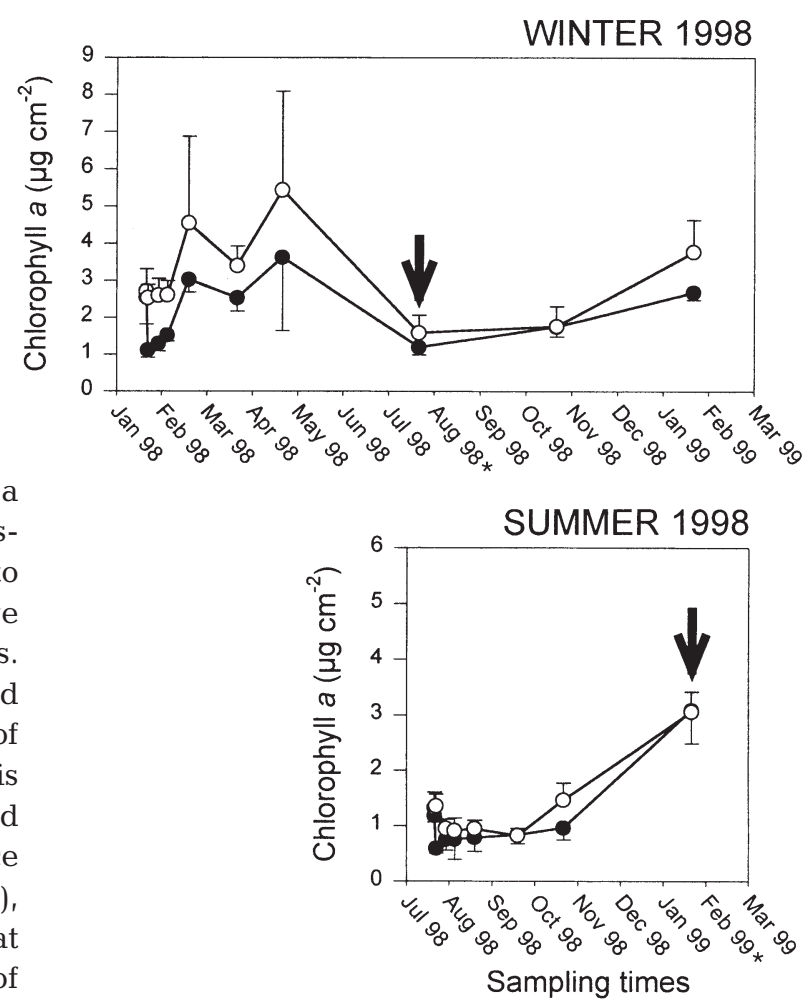

affect local shores. Abugov (1982) suggests that the 'temporal patterning of disturbance' can play an important role in shaping community structure, and the present study implies that this is indeed the case on Hong Kong shores. The seasonal change in conditions on Hong Kong shores results in the majority of macro- 

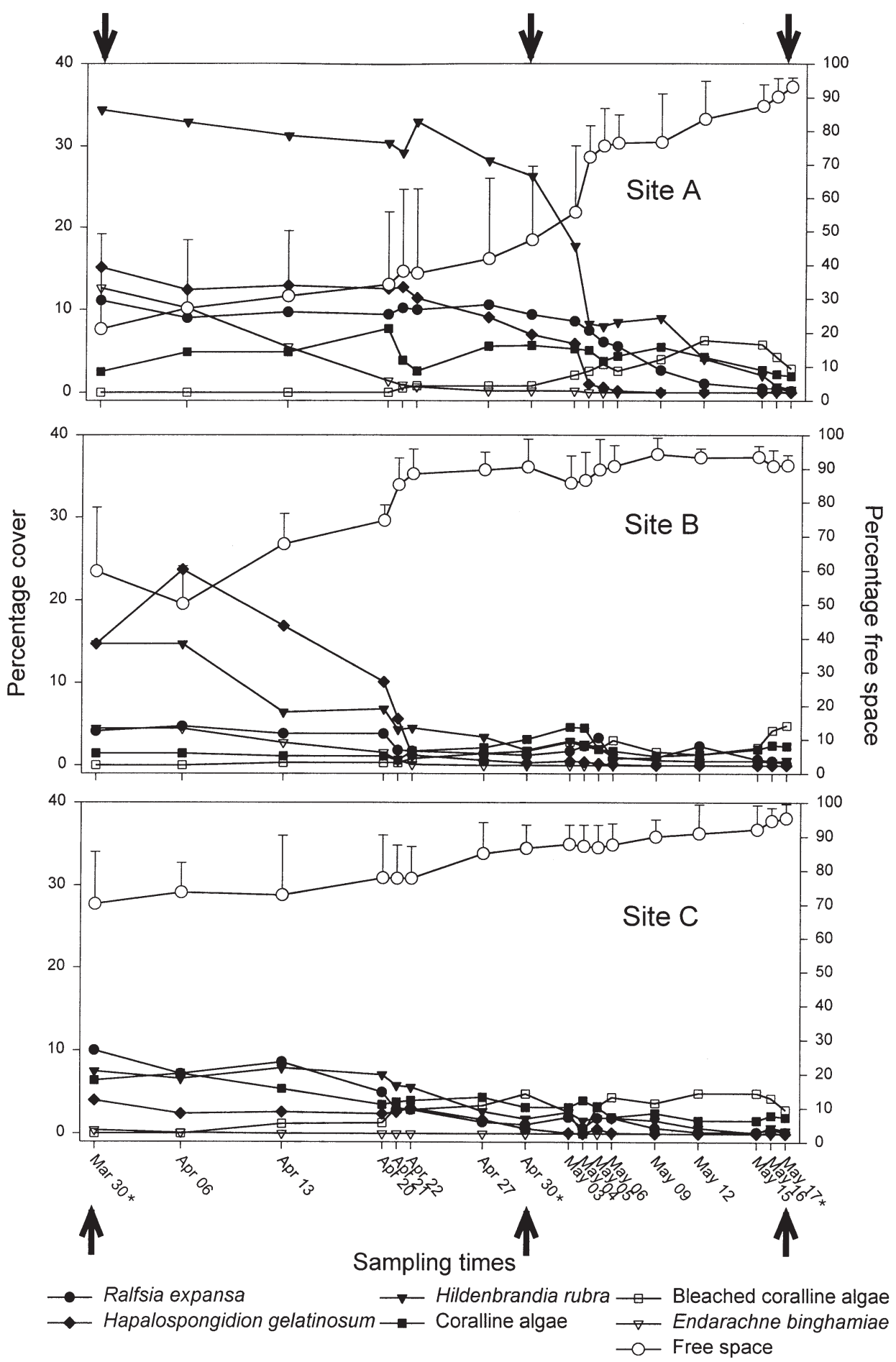

Fig. 5. Summer die-off of algae on transects at Sites A to C on the shore at Cape d'Aguilar, Hong Kong $(\mathrm{n}=10)$. Sampling intensity increases on April 20, May 3 and May 15 to a daily sampling period. Note separate axis for percentage cover (SD bars excluded for clarity) and percentage free space (+SD). Bold arrows and asterisks indicate dates used in statistical analysis

algae disappearing from the shore and a decrease in mobile grazers and sessile invertebrate species (Williams 1994, Williams \& Morritt 1995, Chan 1999, Chan et al. 2001), with only more tolerant species or those in refuges being able to survive (Williams 1993, Kaehler \& Williams 1996).

The occurrence of some types of natural disturbance events are known to be highly variable over a 
Table 3. Summer die-off on transects in Sites A to C at Cape d'Aguilar. Comparison using a 2-factor ANOVA of percentage cover, chl a concentration and grazer abundance in random quadrats on 3 sampling dates, i.e. March 30 (Ma), April 30 (Ap) and May 17 $(\mathrm{My})$. Free space and coralline algae data were arc-sine-transformed, Ralfsia expansa data were ln-transformed, and Hapalospongidion gelatinosum and total grazer abundance data were square-root-transformed where necessary to homogenise variances. Significant differences are shown in bold and fixed factors are further analysed using SNK tests $\left({ }^{\text {snk }}\right)$

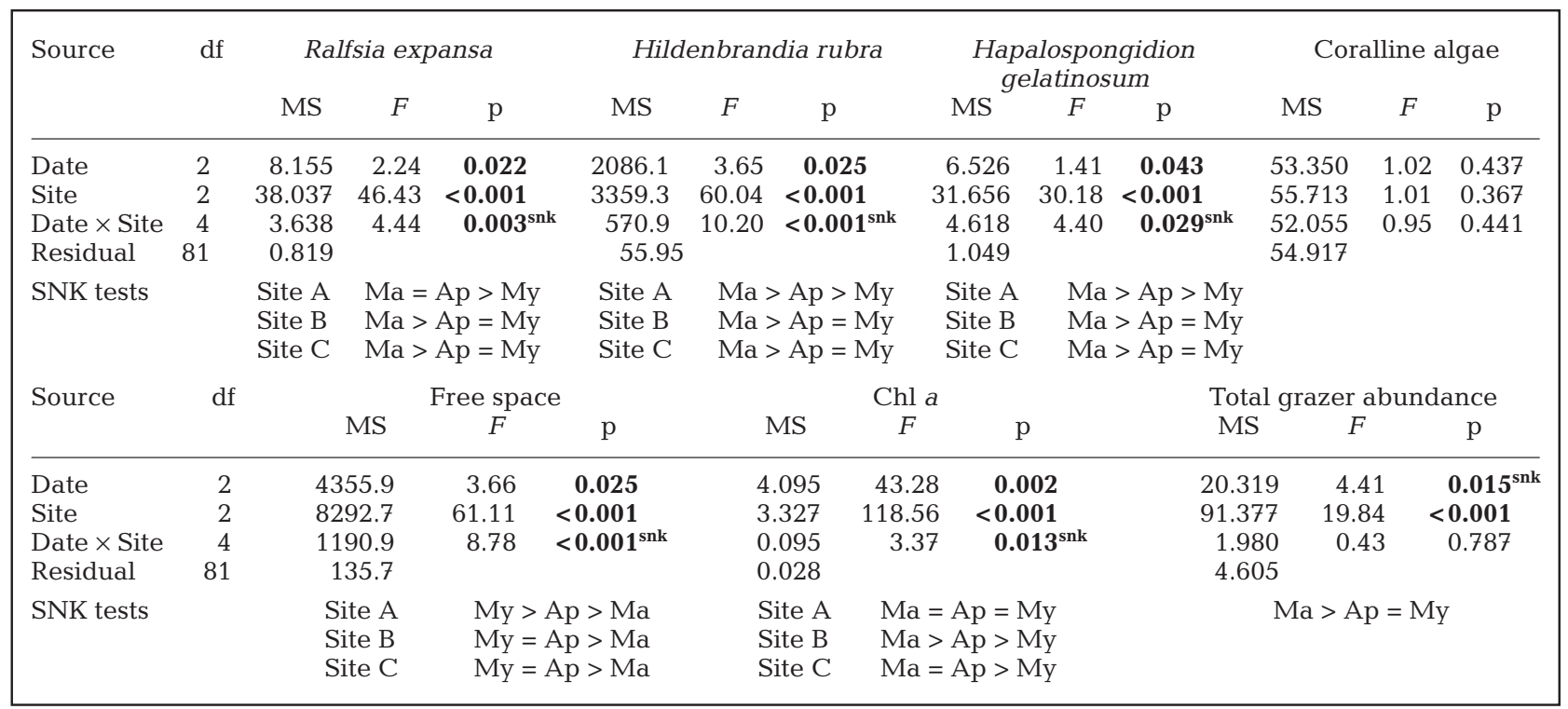

variety of spatial and temporal scales, and recovery from these events may be a lengthy process (Cooper 1966, Daly \& Mathieson 1977, Shanks \& Wright 1986, McCook \& Chapman 1991, Minchinton et al. 1997, Underwood 1998). Typhoon Victor is an example of a pulse disturbance, in that it was a discrete event that caused damage over a short period of time. Within the site at Wah Fu, the typhoon visibly affected only a small area of the shore, possibly due to the presence of cobbles low on the shore. There was considerable variation in the effect of the typhoon at smaller scales within this area (approximately $15 \mathrm{~m}$ in length), depending on where cobbles and possibly wave-born debris impacted the rock surface. Other records of typhoon damage in Hong Kong have also noted the localised impact on certain areas of shore, especially due to sand deposition or cobble scour (Nagarkar 1996).

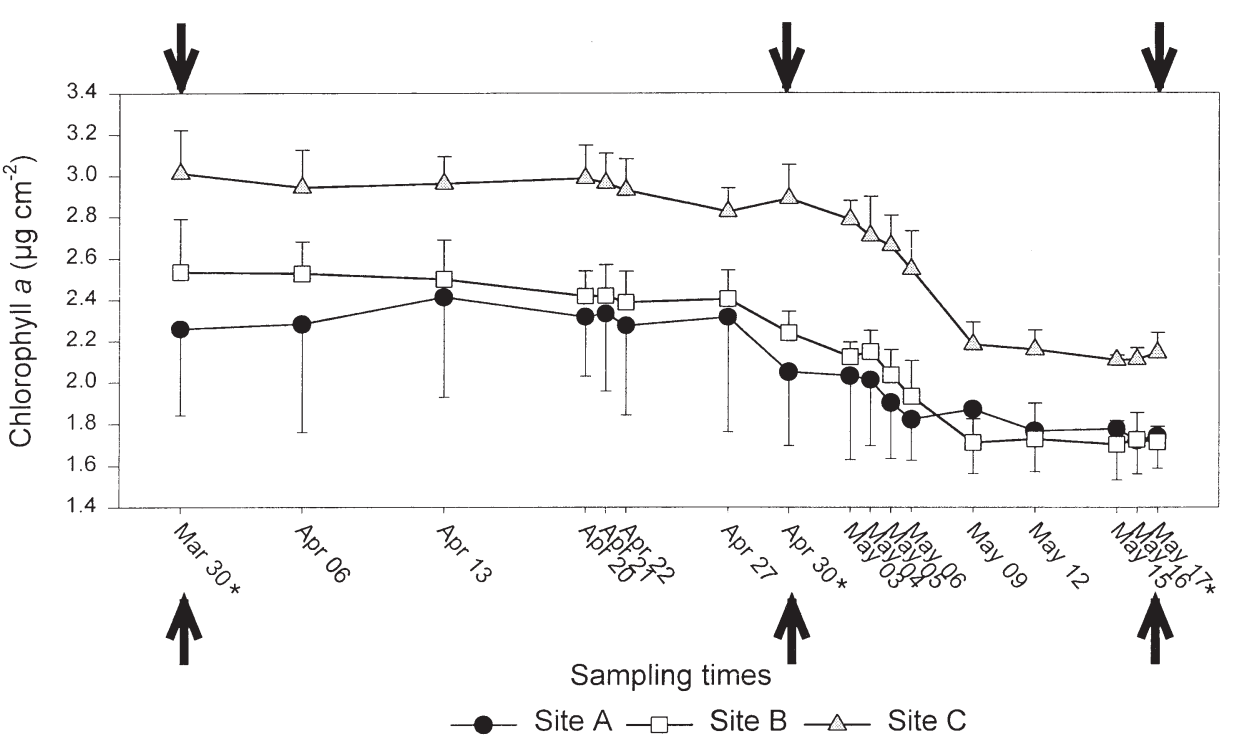

Fig. 6. Variation in mean chl a levels $( \pm \mathrm{SD}, \mathrm{n}=10)$ at $1.5 \mathrm{~m}$ above Chart Datum $(\mathrm{CD})$ during the summer die-off of algae on 3 transects (Sites A to C), Cape d'Aguilar, Hong Kong, 1998. Bold arrows and asterisks indicate dates used in statistical analysis 

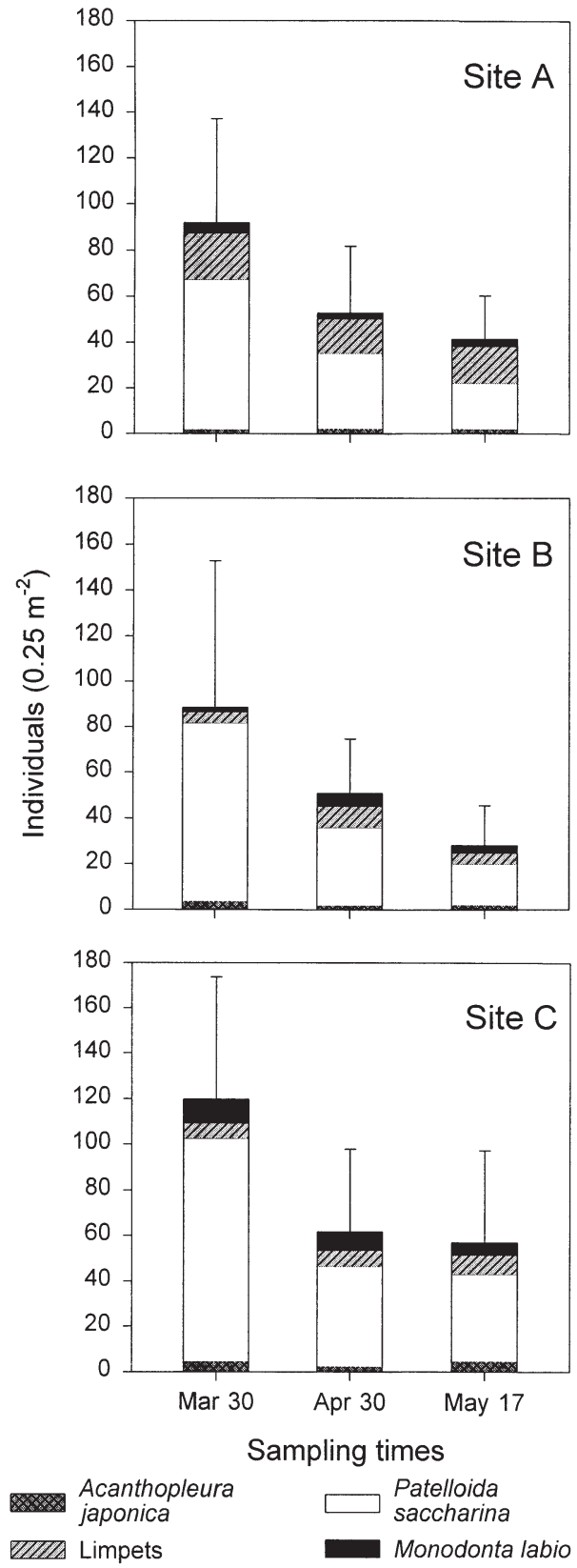

Fig. 7. Abundance of grazers on transects at Sites A to C (+SD for total grazers, $\mathrm{n}=10$ ) at $1.5 \mathrm{~m}$ above Chart Datum (CD) during the summer die-off period at Cape d'Aguilar, Hong Kong, 1998. The category 'Limpets' includes Cellana grata, C. toreuma, Patelloida pygmea and Siphonaria laciniosa. P. saccharina, as the most abundant limpet, was plotted separately

Typhoon disturbance takes place during the summer, at a time when high levels of free space are present elsewhere on shores (Kaehler \& Williams 1996). In contrast to other studies, where localised impacts caused by collision damage are known to have a major structuring effect on intertidal assemblages (e.g. shores where long-lived sessile species dominate the community; Dayton 1971, Dethier 1984), the timing of such events in Hong Kong means that their importance in shaping semi-exposed Hong Kong shores appears to be minimal. Subsequent visits showed that the pattern of recovery following the typhoon was the same as that which occurred after the normal summer die-off the following year (Hutchinson 1999).

Molluscan grazers are known to be affected by storm damage (e.g. Trussell 1997). In the present study, a decrease in the abundance of Monodonta labio was recorded on transect WF1 following the typhoon, which may have had an impact on the patterns of initial algal settlement recorded. This is, however, considered unlikely as the decrease in grazer abundance did not occur at a time when grazing plays a major role in controlling algal growth on Hong Kong shores (Williams 1993). Furthermore, while there was an initial drop in abundance of this molluscan grazer following the typhoon, recolonisation of the disturbed area by the ingress of adult individuals from surrounding undisturbed areas of shore meant that the decrease in grazing pressure was only likely to have occurred over a short time period. While herbivorous crabs and fish do feed on Hong Kong shores (Kennish et al. 1996, Hutchinson \& Williams 2001), and are known to be important in shaping algal assemblages elsewhere in the tropics (Menge 1991), their extremely low abundance at this site (see Williams 1994) during the entire study period (authors' pers. obs.) suggests that the role of these grazers was not important in shaping assemblage composition.

Disturbing fixed plots following the summer die-off had little, if any, effect on the resultant complement of space-occupying species. The lack of rapid algal colonisation in the disturbed plots created in summer can be partly explained by the high levels of physical stress, in particular heat and desiccation stress, that make it difficult for propagules to survive on the shore (Moore 1972, Buschmann 1990, Kaehler \& Williams 1997). As levels of stress decrease (i.e. towards winter), settlement was able to occur and free space was utilised in both undisturbed and disturbed plots, resulting in similar species composition in the different treatments.

Plots disturbed at the beginning of winter, prior to the coolest months of the year, might have been expected to show different patterns of colonisation compared to those disturbed at the beginning of summer, prior to the hottest months of the year. Indeed, numerous studies have found that the creation of free space at different times of the year can result in recruitment by different species (Paine 1977, Sousa 1979b, Dayton et al. 1992). In the present study, however, plots created in winter and summer were colonised by the same species with little variation between plots, the only difference being 
that summer plots remained bare for a longer period of time than plots created in the winter (see BenedettiCecchi \& Cinelli 1993 for similar findings on shores in the Mediterranean). As the scrubbing of experimental plots and typhoon damage on transects totally denuded areas of algae when free space was created, the ability of encrusting algae to recover from disturbance through re-growth of previously damaged tissue (Kaehler 1996, Airoldi 2000) was considered unimportant. Whilst previous studies in Hong Kong (Williams 1993, Kaehler \& Williams 1996, 1997) have shown that erect and encrusting algae recruit at different times of the year, and grazing affects recruitment, the low abundance of grazers in and around experimental plots and the surrounding area (authors' pers. obs.) suggests that grazing was unlikely to be of importance in the present case. As colonisation of plots was by the same species, regardless of season of plot creation, it is more likely that the patterns recorded were due to variation in the impact of physical factors including high temperatures, increased desiccation stress or salinity stress (Hoffmann \& Ugarte 1985).

The seasonal occurrence of encrusting algal species has previously been documented in Hong Kong (Kaehler \& Williams 1996, 1997, Kennish et al. 1996). The summer die-off of algae in Hong Kong occurs over a relatively short period of time, and although sites at Cape d'Aguilar initially varied in percentage cover of algae, the die-off resulted in only refuge-inhabiting species such as Hildenbrandia occidentalis and the bleached remains of coralline algae surviving (also see Kaehler 1996). The decrease in numbers of the limpet Patelloida saccharina was also due to a die-off rather than movement of individual animals from the sites, as they were observed drying out and falling from the rock surface, as has been recorded in previous studies on Hong Kong shores (Williams 1994).

The effect of the different disturbance events was, in each case, to create free space at a variety of spatial scales. In the strongly seasonal Hong Kong climate, the predictable annual summer die-off over rode the effects of both the experimental and natural pulse disturbance events examined, and had a similar impact at the different sites. It appears that the predictable seasonal effect of the onset of summer with increased levels of physical stress, and the subsequent die-off of algae, plays a more important role as compared to discrete, pulse disturbance events in mid-shore assemblage structure. Although assemblages on semiexposed shores examined in Hong Kong are easily disturbed and are not resistant to such events, they appear to be stable over the long term, showing resilience by their ability to return swiftly, in less than $3 \mathrm{mo}$, to a 'normal' state similar to that found prior to disturbance.
Acknowledgements. The authors thank Lisandro BenedettiCecchi for initial statistical advice, Steve Hawkins for helpful comments, and the HKU rocky shore ecology group for critical comments on the manuscript. This research was carried out in partial fulfilment of the requirements for a $\mathrm{PhD}$ submitted by N.H., who was supported by a part-time demonstratorship at the University of Hong Kong. Permission to work in the Cape d'Aguilar Marine Reserve was granted by the Agriculture, Fisheries and Conservation Department, The Government of the Hong Kong SAR. The authors would like to thank the referees for their views, which have been incorporated where possible and have improved the manuscript.

\section{LITERATURE CITED}

Abugov R (1982) Species diversity and phasing of disturbance. Ecology 63:289-293

Airoldi L (2000) Effects of disturbance, life histories, and overgrowth on coexistence of algal crusts and turfs. Ecology 81:798-814

Alvarado JL, Pinto R, Marquet P, Pacheco C, Guiñez, Castilla JC (2001) Patch recolonization by the tunicate Pyura praeputialis in the rocky intertidal of the Bay of Antofagasta, Chile: evidence for self-facilitation mechanisms. Mar Ecol Prog Ser 224:93-101

Aronson RB, Precht WR (1997) Stasis, biological disturbance, and community structure of a Holocene coral reef. Paleobiology 23:326-346

Bell EC (1993) Photosynthetic response to temperature and desiccation of the intertidal alga Mastocarpus papillatus. Mar Biol 117:337-346

Benedetti-Cecchi L, Cinelli F (1993) Early patterns of algal succession in a midlittoral community of the Mediterranean sea: a multifactorial experiment. J Exp Mar Biol Ecol 169:15-31

Blanchette CA (1996) Seasonal patterns of disturbance influence recruitment of the sea palm, Postelsia palmaeformis. J Exp Mar Biol Ecol 197(1):1-14

Buschmann AH (1990) The role of herbivory and desiccation on early successional patterns of intertidal macroalgae in southern Chile. J Exp Mar Biol Ecol 139:221-230

Chan BKK (1999) The ecology of Tetraclita squamosa and Tetraclita japonica (Crustacea: Cirripedia) in Hong Kong. PhD thesis, University of Hong Kong

Chan BKK, Morritt D, Williams GA (2001) The effect of salinity and recruitment on the distribution of Tetraclita squamosa and Tetraclita japonica (Cirripedia; Balanomorpha) in Hong Kong. Mar Biol 138:999-1009

Cooper MJ (1966) Destruction of marine flora and fauna in Fiji caused by the Hurricane of February 1965. Pac Sci 9: 137-141

Daly MA, Mathieson AC (1977) The effects of sand movement on intertidal seaweeds and selected invertebrates at Bound Rock, New Hampshire, USA. Mar Biol 43:45-55

Davis AN, Wilce RT (1987) Algal diversity in relation to physical disturbance: a mosaic of successional stages in a subtidal cobble habitat. Mar Ecol Prog Ser 37:229-237

Dayton PK (1971) Competition, disturbance, and community organization: the provision and subsequent utilization of space in a rocky intertidal community. Ecol Monogr 41: 351-389

Dayton PK, Tegner MJ, Parnell PE, Edwards PB (1992) Temporal and spatial patterns of disturbance and recovery in a kelp forest community. Ecol Monogr 62:421-445

Dethier MN (1984) Disturbance and recovery in intertidal pools: maintenance of mosaic patterns. Ecol Monogr 54:99-118 
Dye AH (1993) Recolonization of intertidal macroalgae in relation to gap size and molluscan herbivory on a rocky shore on the east coast of southern Africa. Mar Ecol Prog Ser 95:263-271

Foster MS (1975) Regulation of algal community development in a Macrocystsis pyrifera forest. Mar Biol 32:331-342

Garrity SD, Levings SC (1981) A predator-prey interaction between two physically and biologically constrained tropical rocky shore gastropods: direct, indirect and community effects. Ecol Monogr 51:267-286

Hartnoll RG, Hawkins SJ (1985) Patchiness and fluctuations on moderately exposed rocky shores. Ophelia 24:53-63

Hawkins SJ, Hartnoll RG (1983) Grazing of intertidal algae by marine invertebrates. Oceanogr Mar Biol Annu Rev 21: 195-282

Hobson RD (1972) Surface roughness in topography: a quantitative approach. In: Chorley RJ (ed) Spatial analysis in geomorphology. Harper \& Row, New York, p 221-245

Hodgkiss IJ (1984) Seasonal patterns of intertidal algal distribution in Hong Kong. Asian Mar Biol 1:49-57

Hoffmann AJ, Ugarte R (1985) The arrival of propagules of marine macroalgae in the intertidal zone. J Exp Mar Biol Ecol 92:83-95

Hong Kong Observatory (1997) Monthly weather summary. The Observatory, Hong Kong

Hutchinson N (1999) Spatial variation on tropical rocky shores: the role of herbivory and disturbance. $\mathrm{PhD}$ thesis, University of Hong Kong

Hutchinson N, Williams GA (2001) Spatio-temporal variation in recruitment on a seasonal, tropical rocky shore: the importance of local versus non-local processes. Mar Ecol Prog Ser 215:57-68

Isaac WE (1933) Some observations and experiments on the drought resistance of Pelvetia canaliculata. Ann Bot 47: 343-348

Kaehler S (1996) Causes and consequences of the spatial and temporal distribution of encrusting algae on tropical rocky shores. PhD thesis, University of Hong Kong

Kaehler S, Williams GA (1996) Distribution of algae on tropical rocky shores: spatial and temporal patterns of non-coralline encrusting algae in Hong Kong. Mar Biol 125:177-187

Kaehler S, Williams GA (1997) Do factors influencing recruitment ultimately determine the distribution and abundance of encrusting algae on seasonal tropical shores? Mar Ecol Prog Ser 156:87-96

Kennish R, Williams GA, Lee SY (1996) Algal seasonality on an exposed rocky shore in Hong Kong and the dietary implications for the herbivorous crab Grapsus albolineatus. Mar Biol 125:55-64

Kohn AJ, Leviten PJ (1976) Effect of habitat complexity on population density and species richness in tropical intertidal predatory gastropod assemblages. Oecologia 25: 199-210

Kostylev V (1996) Spatial heterogeneity and habitat complexity affecting marine littoral fauna. PhD thesis, Göteborg University

Lively CM, Raimondi PT, Delph LF (1993) Intertidal community structure: space-time interactions in the northern Gulf of California. Ecology 74:162-173

McCook LJ, Chapman ARO (1991) Community succession following massive ice-scour on an exposed rocky shore: effects of Fucus canopy algae and of mussels during late succession. J Exp Mar Biol Ecol 154:137-169

McCook LJ, Chapman ARO (1993) Community succession following massive ice-scour on a rocky intertidal shore: recruitment, competition and predation during early, primary succession. Mar Biol 115:565-575
McQuaid CD, Dower KM (1990) Enhancement of habitat heterogeneity and species richness on rocky shores inundated by sand. Oecologia 84:142-144

Menge BA (1991) Relative importance of recruitment and other causes of variation in rocky intertidal community structure. J Exp Mar Biol Ecol 146:69-100

Menge BA, Sutherland JP (1987) Community regulation: variation in disturbance, competition, and predation in relation to environmental stress and recruitment. Am Nat 130: $730-757$

Menge BA, Farrell TM, Olson AM, Tamelen PV, Turner T (1993) Algal recruitment and the maintenance of a plant mosaic in the low intertidal region on the Oregon coast. J Exp Mar Biol Ecol 170:91-116

Minchinton TE, Scheibling RE, Hunt HL (1997) Recovery of an intertidal assemblage following a rare occurrence of scouring by sea ice in Nova Scotia, Canada. Bot Mar 40: $139-148$

Moore HB (1939) The colonization of a new rocky shore at Plymouth. J Anim Ecol 8:29-38

Moore HB (1972) Aspects of stress in the tropical marine environment. Adv Mar Biol 10:217-269

Morton B, Morton J (1983) The sea shore ecology of Hong Kong. Hong Kong University Press, Hong Kong

Nagarkar S (1996) The ecology of intertidal epilithic biofilms with special reference to cyanobacteria. PhD thesis, The University of Hong Kong

Nagarkar S, Williams GA (1997) Comparative techniques to quantify cyanobacteria dominated epilithic biofilms on tropical rocky shores. Mar Ecol Prog Ser 154:281-291

Nagarkar S, Williams GA (1999) Spatial and temporal variation of cyanobacteria-dominated epilithic communities on a tropical shore in Hong Kong. Phycologia 38(5):385-393

Paine RT (1977) Controlled manipulations in the marine intertidal zone and their contributions to ecological theory. In: The changing scenes in the natural sciences, 1776-1976, Special Publ 12. Academy of Natural Sciences, Philadelphia, p 245-270

Paine RT, Levin SA (1981) Intertidal landscapes: disturbance and the dynamics of pattern. Ecol Monogr 51:145-178

Pickett STA, White PS (1985) Patch dynamics: a synthesis. In: Pickett STA, White PS (eds) The ecology of natural disturbance and patch dynamics. Academic Press, London

Pye Finch KA (1943) The intertidal ecology of Bardsey Island, North Wales, with special reference to the recolonization of rock surfaces and the rockpool environment. J Anim Ecol 19:82-108

Shanks AL, Wright WG (1986) Adding teeth to wave action: the destructive effects of wave-borne rocks on intertidal organisms. Oecologia 69:420-428

Sousa WP (1979a) Disturbance in marine intertidal boulder fields: the nonequilibrium maintenance of species diversity. Ecology 60:1225-1239

Sousa WP (1979b) Experimental investigations of disturbance and ecological succession in a rocky intertidal algal community. Ecol Monogr 49:227-254

Sousa WP (1984) Intertidal mosaics: patch size, propagule availability and spatially variable patterns of succession. Ecology 65:1918-1935

Southward AJ, Southward EC (1978) Recolonization of rocky shores in Cornwall after use of toxic dispersants to clean up the Torrey Canyon spill. J Fish Res Board Can 35: 682-706

Stirling HP (1977) Effects of a spill of marine diesel oil on the rocky shore fauna of Lamma Island, Hong Kong. Environ Pollut 12:93-117

Townsley SJ, Trott L, Trott E (1962) A preliminary report on 
the rehabilitation of the littoral marine community on a new lava flow at Kapoho, Hawaii. Ecology 43:728-730

Trussell GC (1997) Phenotypic selection in an intertidal snail: effects of a catastrophic storm. Mar Ecol Prog Ser 151: $73-79$

Underwood AJ (1997) Experiments in ecology. Cambridge University Press, Cambridge

Underwood AJ (1998) Grazing and disturbance: an experimental analysis of patchiness in recovery from a severe storm by the intertidal alga Hormosira banksii on the rocky shores in New South Wales. J Exp Mar Biol Ecol 231:291-306

Underwood AJ, Jernakoff P (1984) The effects of tidal heights, wave-exposure, seasonality and rock-pools on grazing and the distribution of intertidal macroalgae in New South Wales. J Exp Mar Biol Ecol 75:71-96

Underwood AJ, Denley EJ, Moran MJ (1983) Experimental analyses of the structure and dynamics of mid-shore rocky intertidal communities in New South Wales. Oecologia 56: 202-219

van Tamelen PG (1996) Algal zonation in tidepools: experimental evaluation of the roles of physical disturbance, herbivory and competition. J Exp Mar Biol Ecol 201:197-231

Editorial responsibility: Otto Kinne (Editor),

Oldendorf/Luhe, Germany van Tamelen PG, Stekoll MS, Deysher L (1997) Recovery processes of the brown alga Fucus gardneri following the 'Exxon Valdez' oil spill: settlement and recruitment. Mar Ecol Prog Ser 160:265-277

Williams GA (1993) Seasonal variation in algal species richness and abundance in the presence of molluscan herbivores on a tropical rocky shore. J Exp Mar Biol Ecol 167: 261-275

Williams GA (1994) The relationship between shade and molluscan grazing in structuring communities on a moderately-exposed tropical rocky shore. J Exp Mar Biol Ecol 178:79-95

Williams GA, Morritt D (1995) Habitat partitioning and thermal tolerance in a tropical limpet, Cellana grata. Mar Ecol Prog Ser 124:89-103

Williams GA, McMahon BR (1998) Haemolymph pH and oxygen levels in a naturally stressed tropical limpet, Cellana grata. In: Morton B (ed) The marine biology of the South China Sea. Proc Third Int Conf Marine Biology of the South China Sea. Hong Kong University Press, Hong Kong, p 239-245

Zar JH (1996) Biostatistical analysis. Prentice-Hall International, London

Submitted: March 26, 2002; Accepted: November 14, 2002

Proofs received from author(s): February 17, 2003 